\title{
EFFICACY OF BACILLUS THURINGIENSIS VAR. ISRAELENSIS AGAINST THE LARVAE OF AEDES AEGYPTI
}

\author{
MURSHIDA BEGUM $^{1 *}$, HOMAIRA AKBAR ${ }^{1}$, MIHIR LAL SAHA ${ }^{2}$ AND \\ HUMAYUN REZA KHAN ${ }^{1}$ \\ 1. Department of Zoology, University of Dhaka, Dhaka-1000, Bangladesh \\ 2. Department of Botany, University of Dhaka, Dhaka-1000, Bangladesh
}

\begin{abstract}
Efficacy of aqueous suspension of Bacillus thuringiensis var. israelesis (Bti) was studied against the laboratory reared $3^{\text {rd }}$ and $4^{\text {th }}$ instar larvae of Aedes aegypti. Mortality rates as well as histological changes in the larval midgut due to toxic effect of Bti were investigated. Several microscopic techniques were also used to identify the toxic effect on the mosquito larvae. The highest mortality rate $(96.66 \%)$ was found in case of $3^{\text {rd }}$ instar larvae at $1.0 \mu 1 / \mathrm{ml}$ dose where $\mathrm{LC}_{50}$ value was 0.0097 . Larval mortalities increased significantly to $A$. aegypti as doses increased $(\mathrm{p}<0.05)$. Histological study revealed that cellular layers of the midgut epithelium were intact in control sample, but in case of the Bti treated larvae none of these were found in the midgut, only bacterial spores were seen. Results of the microscopic studies indicated that, among the six different colonies found in bacterial cultures, Bti spore, sporangium and vegetative cells were confirmed from one colony by phase transition and fluorescent microscopy. The Cry (crystals) endotoxins and Bti spore were confirmed by the SEM.
\end{abstract}

Key words: Aedes aegypti, Bacillus thuringiensis var. israelensis, Midgut, Phase transition microscopy, $\mathrm{LC}_{50}$, Scanning electron microscopy

\section{Introduction}

Bacillus thuringiensis var israelensis is a ubiquitous gram positive spore forming bacterium, which produces proteinaceous insecticidal crystal during sporulation that is widely used as an alternative to synthetic chemical pestcides (Mendoza et al. 2012 and Ferre and Van Rie 2002).The Bti-crystals are $\beta$-sheet aggregates of a ca. 130 KDa protein that is actually a protoxin and must be activated by certain mid gut proteases to become a 60 to $65 \mathrm{KDa}$ active toxin, which is highly insoluble in normal pH condition (Hofte and Whitely 1989, Schnepf et al. 1998 and Knowles and Dow 1993). In vitro studies of the cytolytic activity of the number of Cry toxin have revealed that the toxicity affects the Lepidopteran and Dipteran cell lines (Knowles and Ellar 1987 and Thomas and Ellar 1983).The molecular mechanisms of Cry-toxins have been discussed intensively, with several hypothesis based cascades of multi-step activities (de Maaged et al. 2001 and Knowles and Dow 1993). During these steps of route, the active toxin passes through the

\footnotetext{
* Corresponding author: E-mail: murshida.begum@du.ac.bd
} 
peritrophic membrane (PM) and binds to specific receptor of the brush border membrane vescicles (BBMVs) of the midgut epithelial cell (Gill et al. 1992, Hofmann et al.1988 and Van Rie et al. 1989).

Therefore, the structure and functional properties of the PM for Bt-toxicity are of vital importance. However, the interaction of Cry toxins with the PM, a major component of the mid-gut lumen, is not well understood (Granados et al. 2001). Biotechnologists and entomologists agree that mosquito control efficiency should be with selectivity for a specific target organism. New control methodologies aim at reducing mosquito breeding sites and biting activity. Combination of chemical-biological control methods for decreasing the population of mosquito and to regulate the man-vector contact has also required (Service 2008). B. thuringiensis var. israelensis has been proved to be successful weapon for fighting against mosquito. The present study was carried out to investigate the effect on toxicity and microbial activity of Bti against $A$. aegypti.

\section{Materials and Methods}

The selected strain of Bacillus used throughout the experiment was Bacillus thuringiensis var. israelensis (Bti). The aqueous suspension of Bti containing 1200 International unit $/ \mathrm{ml}$ with $1.2 \%$ active ingredient and $98.8 \%$ inert ingredient was collected from the laboratory for Plant and Food Science, School of Agriculture, Food and Wine, University of Adelaide, Australia. One $\mathrm{ml}$ of Bti was dissolved in one liter of distilled water to prepare $1 \mu \mathrm{l} / \mathrm{ml}$ solution. This solution was diluted 10 times to formulate $0.1 \mu \mathrm{l} / \mathrm{ml}$ dose and 0.01 and $0.001 \mu 1 / \mathrm{ml}$ Bti doses were prepared accordingly.

A. aegypti was reared in the laboratory of The Department of Zoology, University of Dhaka in an ambient environmental condition at $28 \pm 6^{\circ} \mathrm{C}$ and $70-80 \% \mathrm{RH}$. The adult mosquitoes were kept in a rearing cage made of steel frame, covered with mesh net $(30 \times 30 \times 30 \mathrm{~cm}$ in size $)$. The larvae were kept in a water plastic bowl $(7 \mathrm{~cm}$ in diameter $)$ covered with a piece of fine mesh net. The larvae were fed with cereals and adult female mosquitoes were fed with pigeon blood meal. Adult males were supplied with sugar solution soaked in wads of cotton wool.

A batch of 20 healthy, laboratory reared $3^{\text {rd }}$ and $4^{\text {th }}$ instar larvae of $A$. aegypti were placed separately in beakers containing $200 \mathrm{ml}$ Bti solution each containing 1.0, 0.1, 0.01 and $0.001 \mu \mathrm{l} / \mathrm{ml}$ concentration of bacterial doses to determine the mortality of this mosquito. One $\mathrm{ml}$ of Bti was dissolved in $999 \mathrm{ml}$ of distilled water to make $1.0 \mu 1 / \mathrm{ml}$ dose. Other doses of Bti were prepared likewise. A. aegypti larval mortalities after 24 hours were recorded. Besides the bacterial doses, whether other factors were involved in the mortality or not, a control replicate was also used. All bioassay experiments were repeated three times. 
The mean percent of mortalities of different doses of Bti was statistically analyzed using ANOVA. Multiple comparisons were done by Tukey's honest significance test. A probit analysis was also done by following EPA program, version 1.5 for calculating LC values of Bti against $3^{\text {rd }}$ and $4^{\text {th }}$ instar larvae at $95 \%$ confidence limit. Mean percent of mortality and LC values of 3 rd and $4^{\text {th }}$ instar larvae were compared by t-tests in each dose.

Histological slides of the Bti treated $3^{\text {rd }}$ instar larvae of A. aegypti in control and in $0.1 \mu \mathrm{l} / \mathrm{ml}$ were prepared by longitudinal sectioning the tissues of the larval midgut region. Ethanol, Myer's albumin and Xyline were used as fixatives. Serial Longitudinal sections of the tissues were cut at $0.5 \mu \mathrm{m}$ thickness with the help of a rotary microtome machine (model 08-260-02, ERMA INC, Japan). The tissue sections were stained with eosin and Heidenhein's haematoxylene in the laboratory condition.

Bti treated larval midgut samples were streaked onto a Petri - dish containing nutrient agar medium with a sterile platinum loop to find specific bacterial cultures. After overnight incubation at $37^{\circ} \mathrm{C}$, six different bacterial colonies were found in the nutrient agar plate. Subcultures were also done for the six colonies distinguished as sample 1, 2, $3,4,5$ and 6 separately in the same culture media using the same procedure. Each of the above samples was stained following simple staining procedure with Acridine orange and Crystal violet dye. Bacterial spore staining was done by malachite green dye to observe whether Bt spore available or not. All the stained samples were observed under a Nikon Microphot microscope in phase contrast condition. A Nikon optiphot florescent microscope was also used to observe the sample under UV light in bright field condition. Photographs were taken with a Nikon UFX - II camera in all cases. Scanning electron microscopic (SEM) studies were done from the six pre fixed bacterial sample slides. The samples were sputter coated by platinum and processed to observe under a Jeol JSM 6490 LA scanning electron microscope. This technique is necessary for the identification of bacterial spores and crystal (Cry) toxin.

\section{Results and Discussion}

Percent of deceased 3rd and $4^{\text {th }}$ instars larvae of $A$. aegypti at different doses of Bti are presented in Table 1 . The highest mortality was $96.66 \%$ and the lowest mortality was $21.66 \%$ at $1.0 \mu \mathrm{l} / \mathrm{ml}$ and $0.001 \mu \mathrm{l} / \mathrm{ml}$ doses, respectively. No mortality was observed in control for both larval instars. Susceptibilities of laboratory reared $3^{\text {rd }}$ and $4^{\text {th }}$ instars larval A. aegypti to an aqueous suspension of Bti are presented in Table 2. $\mathrm{LC}_{50}$ values for the $3^{\text {rd }}$ instar larvae was $0.0097 \mu 1 / \mathrm{ml}$ and for the $4^{\text {th }}$ instar larvae was $0.0087 \mu 1 / \mathrm{ml}$. There was no significant difference at $5 \%$ level between the $3^{\text {rd }}$ and $4^{\text {th }}$ instar larvae in terms of mortality and LC values. However, significant difference was observed among the doses (Tables 1 and 2$)(\mathrm{F}=8,12 ; \mathrm{SE}=2.31 ; \mathrm{p}<0.05)$. The aqueous suspension of Bti was highly effective against the $3^{\text {rd }}$ and $4^{\text {th }}$ instar larvae of $A$. aegypti (Tables 1 and 2 ). The findings of the present study showed that increasing in the doses of Bti increased the mortality of the mosquito larvae significantly (Table1). These results are in agreement 
with the studies conducted by Ignoffe et al. (1981), Lacey and Lacey (1981), Farghal and Temerak (1981), Ahmed et al. (1986) and Begum et al. (2012), who have showed that $A$. aegypti was very susceptible to Bti. Van Essen and Hembree (1980) determined the $\mathrm{LC}_{50}$ of Bti exposed with the larvae of $A$. aegypti for 72 hours as $0.36 \mathrm{ppm}$. Results of the present experiments are in close agreement to the results of Van Essen and Hembree (1980).

Table 1. Mortality of the $3^{\text {rd }}$ and $4^{\text {th }}$ instar larval Aedes aegygti at different doses of Bacillus thuringiensis var. israelensis after 24 hours exposure $(\mathrm{n}=60)$.

\begin{tabular}{ccc}
\hline Doses & \multicolumn{2}{c}{ Percent of larval mortality (Mean \pm SD) } \\
\cline { 2 - 3 }$(\mu 1 / \mathrm{ml})$ & $3^{\text {rd }}$ instar & $4^{\text {th }}$ instar \\
\hline 0.001 & $26.66 \pm 2.885$ & $25.0 \pm 5.0$ \\
0.01 & $46.66 \pm 5.77 \mathrm{c}$ & $45.0 \pm 5.0 \mathrm{c}$ \\
0.1 & $85.0 \pm 5.0 \mathrm{~b}$ & $83.33 \pm 5.0 \mathrm{~b}$ \\
1.0 & $96.66 \pm 2.885 \mathrm{a}$ & $93.33 \pm 5.0 \mathrm{a}$ \\
\hline
\end{tabular}

* Values of 3 replications of each of which comprised of 20 larvae. Different letters indicates significant difference from the mortality of $0.001 \mu \mathrm{l} / \mathrm{ml}$ dose of Bti $(\mathrm{p}<0.05)$.

Table 2. Susceptibility of laboratory reared Aedes aegypti larvae ( $3^{\text {rd }}$ and $4^{\text {th }}$ instars) to an aqueous suspension of Bacillus thuringiensis var. israelensis $(\mathrm{n}=60)$.

\begin{tabular}{|c|c|c|c|c|c|}
\hline \multirow{2}{*}{$\begin{array}{l}\text { Larval } \\
\text { instars }\end{array}$} & \multicolumn{2}{|c|}{$\mathrm{LC}$ values $(\mu 1 / \mathrm{ml})$} & \multicolumn{2}{|c|}{$95 \%$ confidence limit } & \multirow{2}{*}{$\begin{array}{c}\text { Slope values } \\
\quad \pm S E\end{array}$} \\
\hline & & & Lower & Upper & \\
\hline \multirow{3}{*}{$\begin{array}{c}\text { 3rd } \\
\text { instar }\end{array}$} & $\mathrm{LC}_{50}$ & 0.0097 & 0.002 & 0.023 & \multirow{3}{*}{$0.99 \pm 0.25$} \\
\hline & $\mathrm{LC}_{95}$ & 0.2753 & 0.087 & 2.996 & \\
\hline & & 0.753 & 0.189 & 15.85 & \\
\hline \multirow{3}{*}{$\begin{array}{l}\text { 4th } \\
\text { instar }\end{array}$} & $\mathrm{LC}_{50}$ & 0.0087 & 0.003 & 0.022 & \multirow{3}{*}{$0.83 \pm 0.17$} \\
\hline & $\mathrm{LC}_{95}$ & 0.2413 & 0.079 & 1.990 & \\
\hline & & 0.591 & 0.161 & 8.859 & \\
\hline
\end{tabular}

* Values of 3 replications of each of which comprised of 20 larvae.

Histological study revealed that the cellular layers and tissues of the midgut of the larvae of $A$. aegypti in control were intact (Plate1), but in the Bti treated larvae, no cellular parts were observed, and only bacterial spores were found (Plate 2$)$. The pathological effects of Bti Cry endotoxins ( $\delta$-endotoxin) on susceptible insect larvae are responsible for extensive damage on midgut epithelial cells and biocide characters (Ferre and Van Rie 2002). The most important feature of spore forming Bti is to production of $\mathrm{Cr}$-toxin during sporulation. During proteolytic activation, the active endotoxin of Bti binds to specific receptors in the BBMVs of midgut epithelial cells through PM (Gill et al. 1992, Hofmann et al., 1988 and Van Rie et al. 1989). The PM may involve in several functions 
of critical importance for the insect survival, including defense barrier against ingested parasites, pathogens and toxins (Binnington et al. 1998, Wang and Granados 1997 and Wang and Granados 2000). It has also been reported that midgut epithelial cells of the host are affected and eventually destroyed, probably because of the permeability of the cell membrane is affected (Aronson et al. 1986, Aronson and Wu 1989 and Chilcott et al. 1990). Cry-toxins activated in the cell membrane, form pores and channels in the gut membrane which is followed by the destruction of epithelial cells and paralysis of the digestive system and causes spore germination and septicemia and larval death occurs (Balaraman et al. 1981). The present findings of the histological works are in the agreement with the above mentioned investigators.

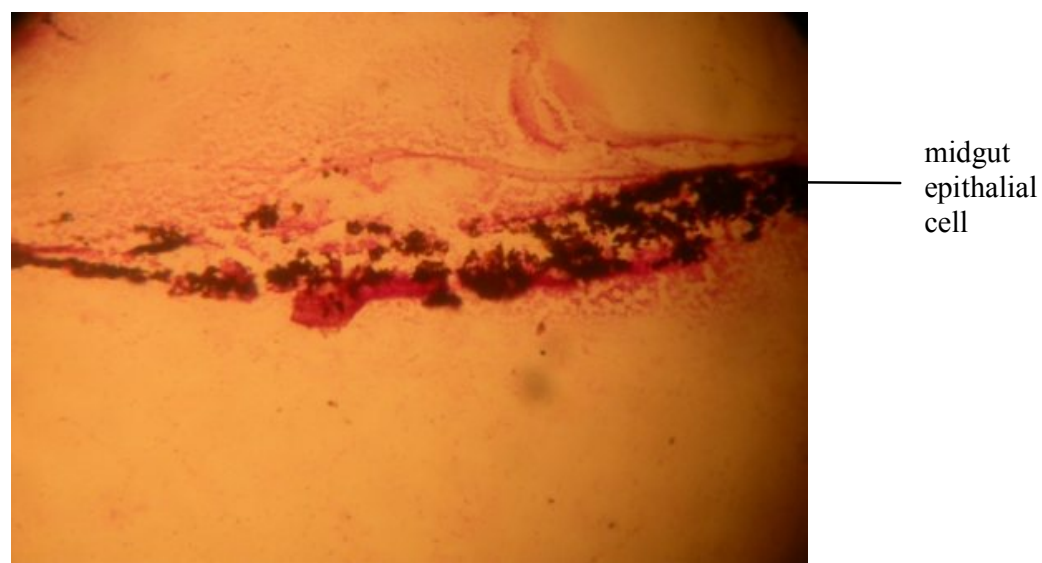

Plate 1. L.S. of the midgut of the $3^{\text {rd }}$ instar larvae of the Ae. aegypti (40X).

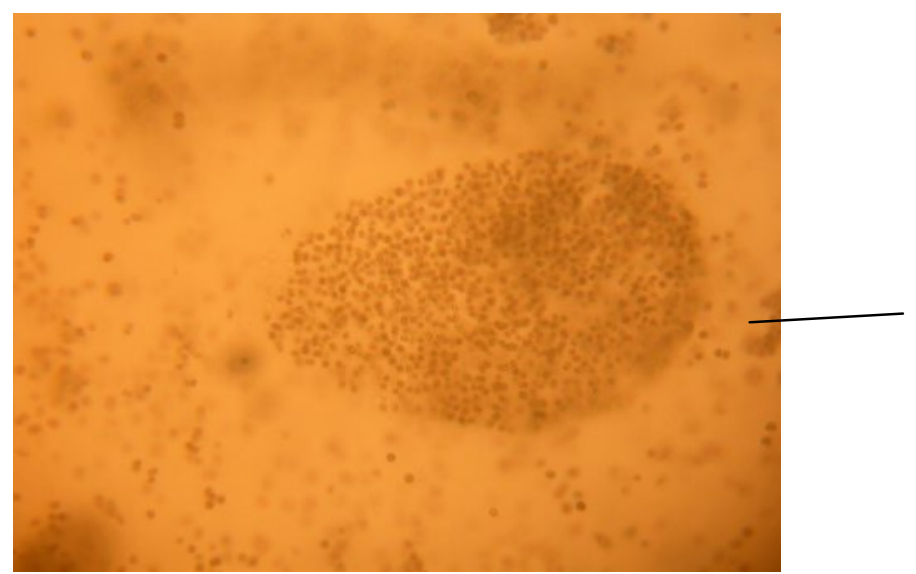

spores

Plate 2. L.S. of the midgut of Bti treated $3^{\text {rd }}$ instar larvae of Ae. aegypti showing only Bti spores; no tissue structures were found(40X). 
The results of histological examination have been made attention on microbial study of the treated larval midgut element by several microscopic techniques, whether Bti Crytoxin identification could be possible or not. Different types of dyes were used in several microscopic studies. Six different colonies were found from the subculture of the mid gut sample. Phase contrast and fluorescent microscopic study showed that among the six different stained with acridine orange, only samples 3 and 6 were rod-shaped and contained spores which were thought to be Bti (Plates $3 \mathrm{~A}$ and B). The spores of the sample 3 were situated in the middle portion of the bacterium and some parts of this bacterium were darker which might be the Cry-endotoxin (Plate 3A). But, in case of the sample 6, the spores were rounded and located in the anterior terminal portion (Plate 3B). Bacterial vegetative cells and spores were also identified in phase contrast microscopic study of the sample 3 stained with malachite green (Plate 4). Vegetative cell, spore and sporangium were also recognized fluorescent microscopic study of sample 3 stained with acridine orange in bright field ailment (Plate 5A). The same bacterial stuffs were also documented under ultraviolet and bright field state of fluorescent microscopic study (Plates 5B and C). Stained with crystal violet, the sample 3 also showed vegetative cells, spore and sporangium under fluorescent microscope in bright field condition (Plate 6). Scanning electron microscopic images of $12000 \mathrm{X}$ from the sample 3 showed spore and possible crystals of Bti (Plate 7).

Vegetative cells, spores, Crystal toxin and paraposal Crystal formation of $B$. thuringiensis species was identified by phase contrast microscopy, fluorescent microscopy, scanning electron microscopy and electron microscopy (Mendoza et al. 2012 and Noguera and Ibarra 2010). Crystal toxin and spores of B. thuringiensis var. thompsoni and B. sphaericus was identified by phase contrast microscopic study (Surendran and vennison 2011). Results of the present investigations are in close agreement with the upshots of research done by above authors. Thus, it may be inferred that the Bti is highly susceptible to the larvae of $A$. aegypti; it causes tissue disruption in the midgut of the larvae of this insect. 

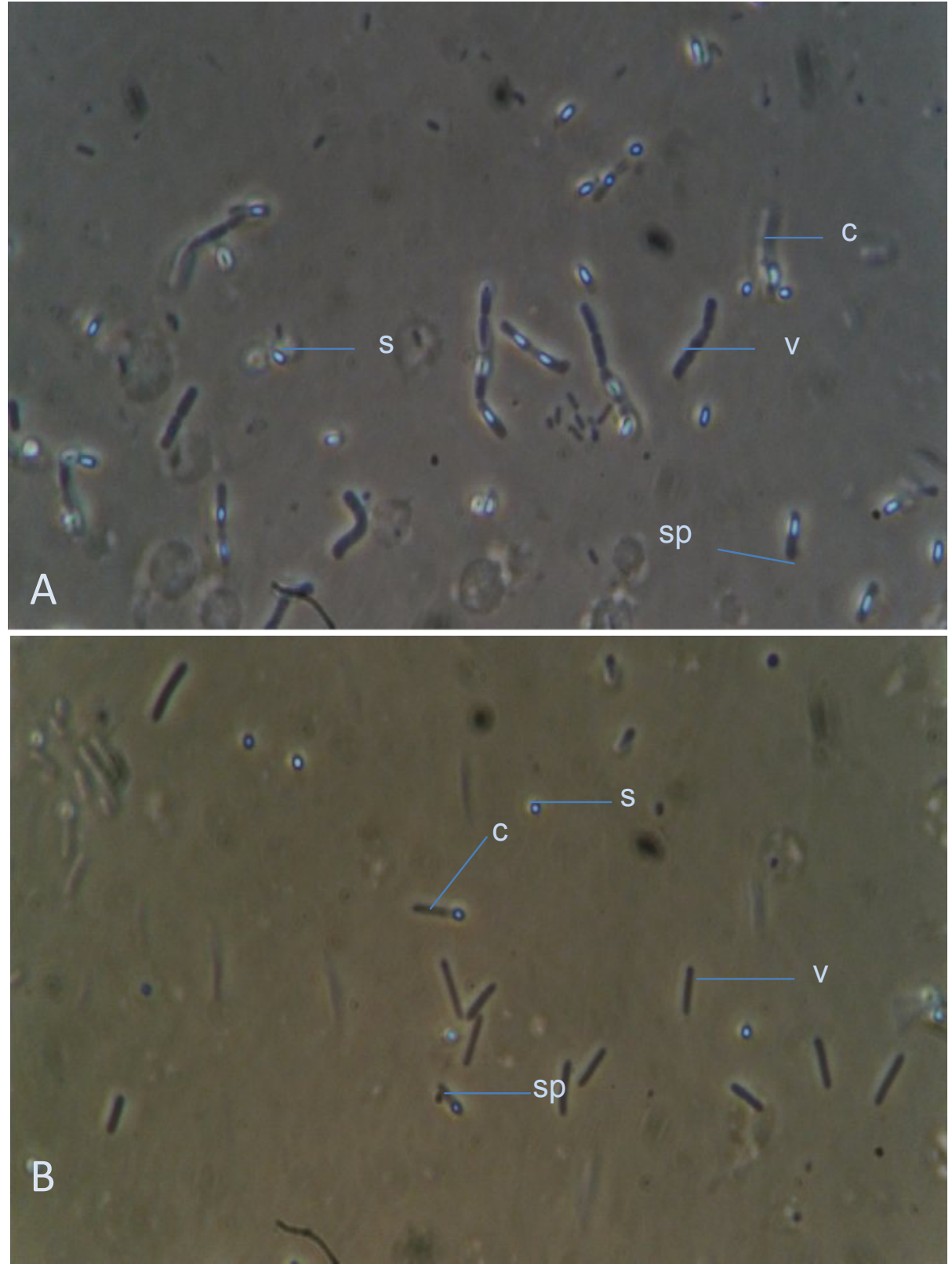

Plate 3. Photomicrograph viewed with phase contrast microscopy under an oil-immersion objective(100X) showing vegetative cells (v), spores(s), sporangia(sp) and crystals(c) of cultured bacterial sample no.3(Plate 3A) and 6( Plate 3B). 


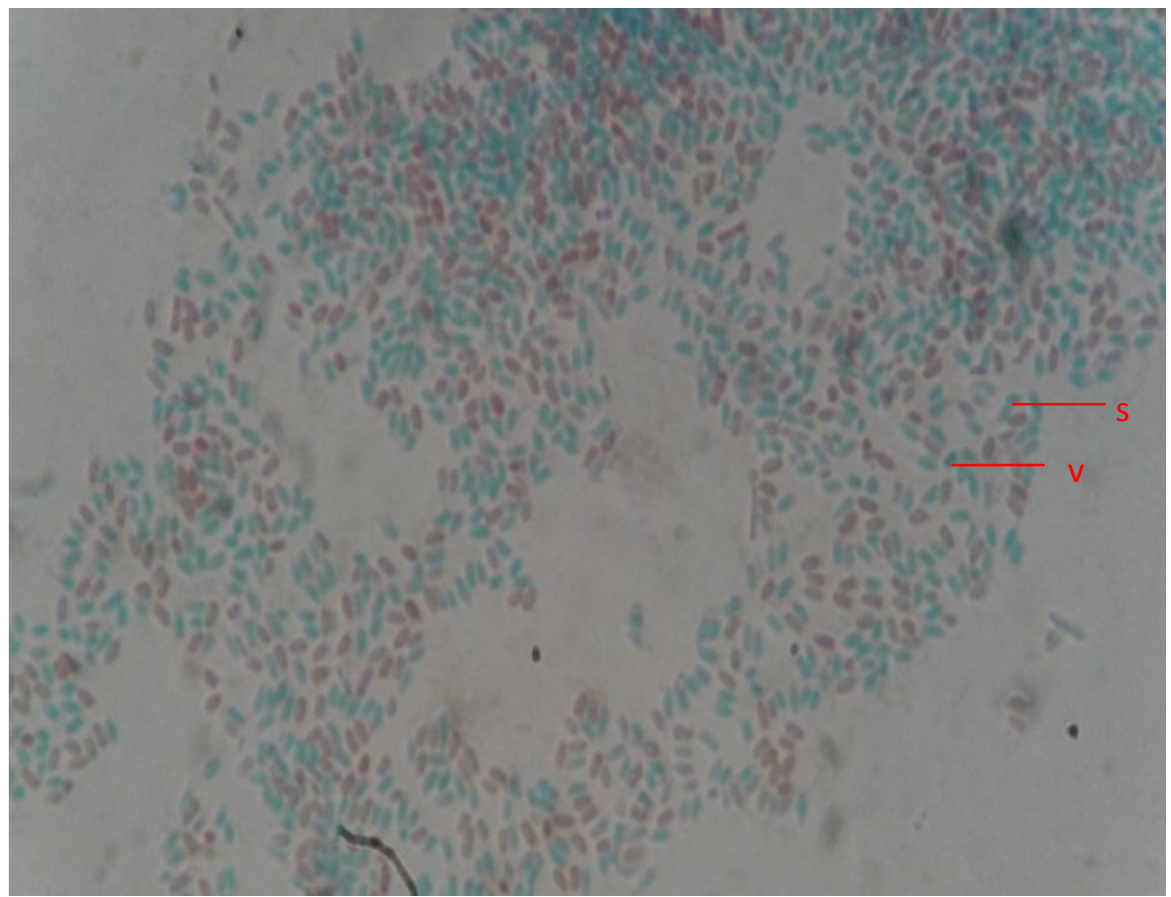

Plate 4. Photomicrograph of sample no. 3 stained with malachite green showing vegetative cells (v) and spores(s).

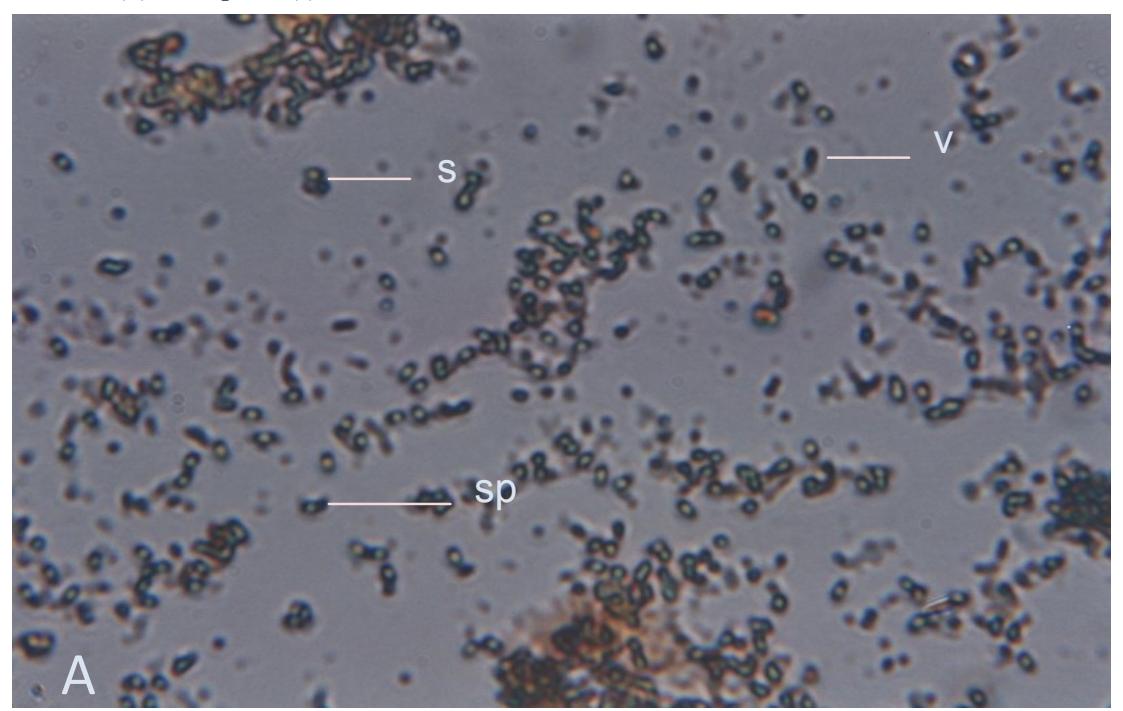

Plate 5A. Photomicrograph of bacterial sample no. 3 stained with acridine orange showing vegetative cell(v), spores(s), and sporangium under bright field microscopy(A) and under fluorescent microscopy( B and C)(100X). 

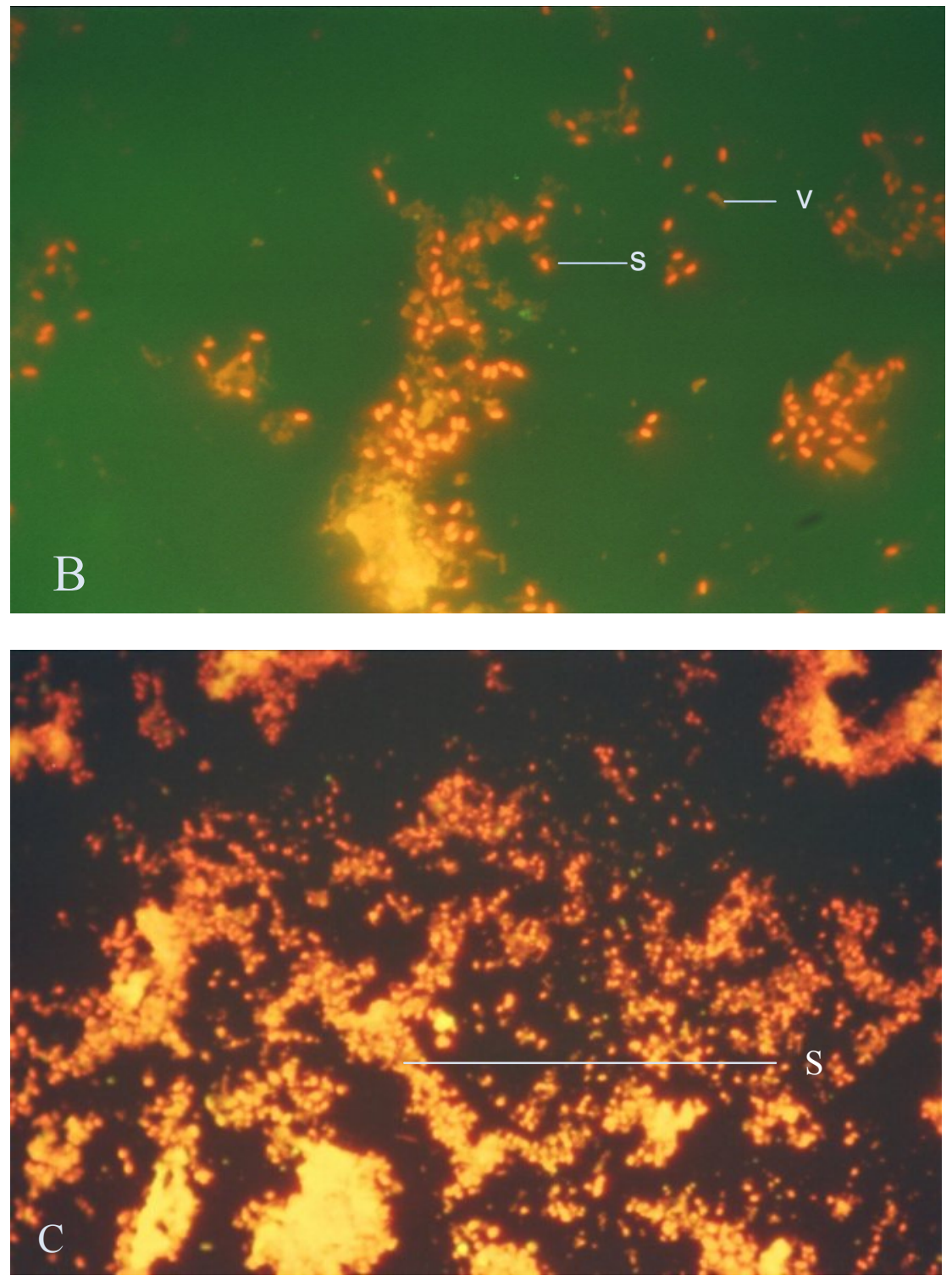

Plates 5B and C. Photomicrograph of bacterial sample no. 3 stained with acridine orange showing vegetative cell(v), spores(s), and sporangium under bright field microscopy(A) and under fluorescent microscopy( B and C)(100X). 


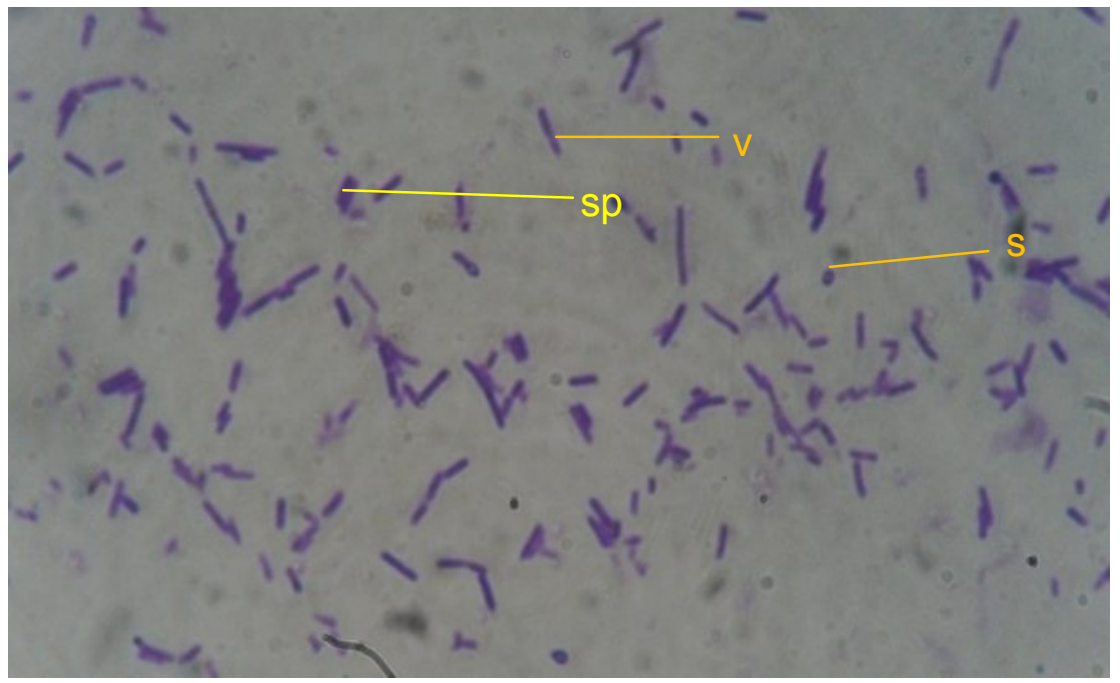

Plate 6. Photomicrograph of bacterial sample no.3 stained with crystal violet showing vegetative cells (v), spores (s) and sporangium (sp) (100X).

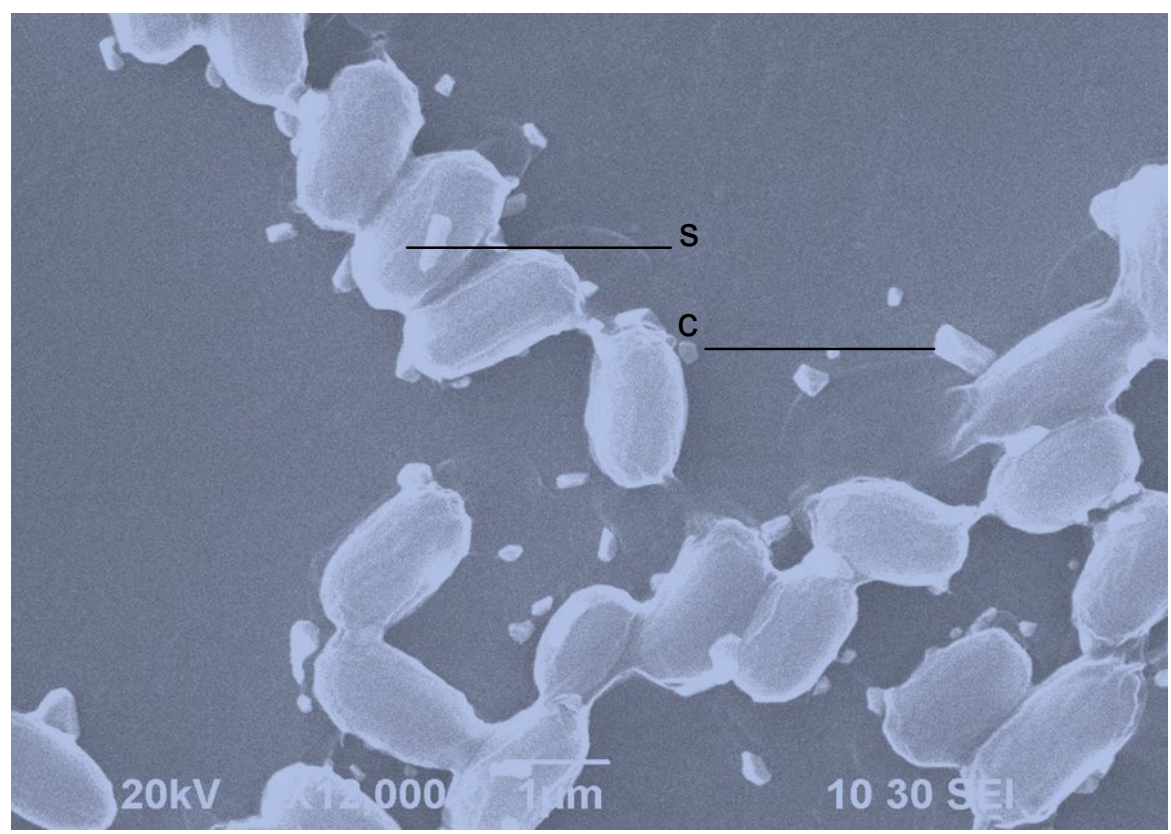

Plate 7. Scanning Electron Microscopic Image of Sample no.3 showing spores (s) and Crystals (c) (12000X). 


\section{References}

Ahmed, A. J., Khoda, M. E. and T. U. Ahmed. 1986. Laboratory study on biological control of mosquitoes by bacteria Bt (Serotype H-4). Bangladesh J. Zool. 1:17-20.

Aronson, A. and D. Wu. 1989. Specificity in vivo and in vitro of Bacillus thuringiensis deltaendotoxins active in Lepidoptera. In: New direct. biol. contl. (Ed., Baker R. and P E Dunn) Liss, New York. pp. 112-115.

Aronson, A. I., W. Beckmen and P. Dunn. 1986. Bacillus thuringiensis and related insect pathogens. Microbiol. Rev. 50:1-24.

Balaramen, K., S. L. Hoti and L. M. Manonmani. 1981. An pathogenic indigenous strain of Bacillus thuringiensis, high pathogenic and specific to mosquitoes. Curnt. Sci. 50:199200.

Begum, M., S. Khan, S. Ahmed, M. F. Rahman and H. R. Khan. 2012. Susceptibility of Culex quinquefasciatus and Aedes aegypti larvae to Bacillus thuringiensis israelensis. Nucl. Sci. Appl. 21(1 and 2):41-45.

Binnington, K. C., M. J. Lehane and C. D. Beaton. 1998. The perithophic membrane. In: F.W. Harison and M. Locke, Editors, Micros. Anat. Invert. 11B: Insecta, Wiley, New York, pp $747-758$.

Chilcott, C. N., B. H. Knowles, D. J. Ellar and F. A. Drobniewski. 1990. Mechanism of action of Bacillus thuringiensis israelensis parasporal boby. J. Econ. Ent. 90:1021-1031.

De maagd, R. A., A. Brava and N. Crickmore. 2001. How Bacillus thuringiensis has evolved specific toxins to colonise the insect world. Trends Gen. 17:193-199.

Farghal, A. L. and S. A. Temerak. 1981. Notes on the pathology of Bacillus thuringiensis var. israelensis for Culex pipiens molestus larvae. J. Pest Res. 19:38-45.

Ferre, J. and J. Van Rie. 2002. Biochemistry and genetics of insect resistance to Bacillus thuringiensis. Annual Rev. Entomol. 47:501-533.

Gill, S.S., E. A. Cowles and P. V. Pietrantonio. 1992. The mode of action of Bacillus thuringiensis endotoxins. Annual Rev. Entomol. 37:625 - 634.

Granados, R. R., Y. Fu, B. Corsaro and P. R. Hughes. 2001. Enhancement of Bacillus thuringiensis toxicity to Lepidoptera species with the enhancin from Trichoplusia nigrnulovirus. Biol. Control. 20:153-159.

Hofmann, C., H. Vanderruggen, H. Hofte, J. V. Rie, S. Jansens and H. V. Mellaert. 1988. Specificity of Bacillus thuringiensis delta - endotoxins is correlated with the presence of high affinity binding sites in the brush border membrane of the taget insect midguts. Proc. Natl. acad. of Sci. 85: 7844-7848.

Hofte, H. and H. R. Whitley. 1989. Insecticidal crystal proteins of Bacillus thuringiensis. Microbiol. Rev. 53:242-255.

Ignoffo, C. M., C. Garcia, M. J. Kroha, T. Fukuda and T. L. Couch. 1981. Laboratory tests to evaluate the potential efficiency of Bacillus thuringiensis var. israelensis for use against mosquitos. Mosq. News. 41:85-93.

Knowles, B. H., and D. J. Ellar. 1987. Colloid osmotic lysis is a general feature of the mechanism of action of Bacillus thuringiensis [delta]-endotoxins with different insect specificity. Biochem. Biophys. Acta. 924:509-518.

Knowles B. H. and J. A. T. Dow. 1993. The crystal endotoxins of Bacillus thuringiensis models for thier mechanism of action on the insect gut. Bio Essays. 15:469-476.

Lacey, L. A. and J. M. Lacey. 1981. The larvicidal activity of Bacillus thuringiensis var. israelensis (H-14) mosquitoes of the Central Arizona Basin. Mosq. News. 41:266-270.

Mendoza, G., A. Portillo, E. Arias, M. R. Ribas and J. Olmos. 2012. New combinations of cry genes from Bacillus thuringiensis strains isolater from northwestern Mexico. Int. Microbiol. 15(4):209-216.

Noguera, P. A. and J. E. Ibarra. 2010. Detection of new cry genes of Bacillus thuringiensis by use of a novel pcr primer system. Appl. Environ. Microbiol. 76(18):6150-6155. 
Schnepf, E., N. Crickmore, J. Van Rie, D. Lereclus, J. Baum, J. Feitelson, D. R. Zeigler, and D. H. Dean. 1998. Bacillus thuringiensis and its pesticidal crystal proteins. Microbiol. Mol. Biol. Rev. 62:775-806.

Service, M. 2008. Medical entomology for students. Cambridge University Press. 289pp.

Surendran, A and S. J. Vennison. 2011. Transfer of toxin coding megaplasmid of Bacillus thuringiensis subsp. Thompsoni into Bacillus sphaericus. In. J. Appl. Biol. Pharm. Tech. 2(3): $366-373$.

Thomas, W. E. and D. J. Ellar. 1983. Bacillus thuringiensis var. israelensis crystal delta endotoxin: effects on insect and mammalian cells in vitro and in vivo. J. Cell Sci. 60:181-97.

Van Essen, F. W. and S. C. Hembree. 1980. Laboratory bioassay of Bacillus thuringiensis against all instars of Aedes aegypti larvae. Mosq. News. 40:424-431.

Van Rie, J., H. Hofte, D. Degheele, and H. Van Mellaert. 1989. Specificity of Bacillus thuringiensis delta - endotoxins. Importance of specific receptors on the brush border membrane of the mid gut of target insects. European J. Biochem. 186: 239-247.

Wang, P. and R. R. Granados. 1997. An intestinal mucin is the target substance for a baculovbirus enhencin. Proc. Nat. Acad. Sci. 94: 6977-6982.

Wang, P. and R. R. Granados. 2000. Calcufluor disrupts the midgut defense system in insects. Insect Biochem. Mol. Biol. 30: 135-143. 